\title{
Enhancing Students`Mathematical Problem Solving Ability Through Brain Based Learning Approach
}

\author{
$1^{\text {st }}$ Nurul Afifah Rusyda \\ Mathematics and Science Faculty \\ Universitas Negeri Padang \\ Padang, Indonesia \\ nurulrusyda@fmipa.unp.ac.id
}

\author{
$2^{\text {nd }}$ Rusdinal \\ Educational Science Faculty \\ Universitas Negeri Padang \\ Padang, Indonesia \\ rusdinalhar@yahoo.com
}

\author{
$3^{\text {rd }}$ Fitrani Dwina \\ Mathematics and Science Faculty \\ Universitas Negeri Padang \\ Padang, Indonesia \\ fitrani_mat@fmipa.unp.ac.id
}

\begin{abstract}
The aim of this research is to analyze whether the learning with BBL approach could increase students' mathematical problem-solving ability based on Mathematical Preliminary Skills (MPS). This research type is quasiexperimental with nonequivalent control group design. The population was all $7^{\text {th }}$-grade students in one of the junior high schools in Padang. The topic chosen in this study is geometry. The data collecting instrument is tested. The result shows that the enhancement of the mathematical problem-solving ability of students who learn based on Brain-Based Learning (BBL) approach is significantly higher than students who learn based on conventional learning (CL) based on MPS (high, medium, low).
\end{abstract}

Keywords-Brain-based learning, Mathematical preliminary skills, Mathematical problem-solving ability

\section{INTRODUCTION}

Mathematical problem-solving ability is one of the important goals in learning mathematics. Having problemsolving ability helps students to think analytically in making the decision and to improve mathematical problem-solving ability in facing the new situation [1]. In fact, the level of problem-solving ability of Indonesian students is still under expectation in solving non-routine problems [2]. The highest score in International is $66 \%$ participants of TIMSS that can solve the problem successfully. But, for Indonesia only $11 \%$ participants of TIMSS that can solve the problem successfully [3].

The low ability on geometry problem solving caused by some factors: the students are not familiar with mathematical problem; the weak memory of previous knowledge; and lack of problem-solving framework [4]. In addition, students' common mistakes in solving the problem of mathematical problem solving are carelessness or inaccuracy, errors in transforming information, process skill errors, and misunderstanding of the problems [5]. Unluckily, students' mathematical problem-solving ability also has a lower average score than mathematical communication ability [6].

Based on the mathematical problem-solving ability that wants to be enhanced, then mathematics learning using the Brain-Based Learning (BBL) approach is thought to be able to improve the ability of mathematical problem-solving. The Brain-Based Learning (BBL) is an approach that reflect our understanding of how our brain works in the context of education [7]. In addition, he BBL approach creates learning that is oriented towards empowering brain potential [8]. There are three main strategies that can be developed in the implementation of the BBL approach: (1) creating a learning environment that challenges students' thinking abilities; (2) creating a pleasant learning environment, (3) creating an active learning situation and meaningful for students (attractive learning) [7].

The BBL approach has seven stages of learning; (1) preexposure; (2) preparation; (3) initiation and acquisition; (4) elaboration; (5) incubation and encoding memory; (6) verification and checking of trust; and (7) celebration and integration. The pre-exposure and preparation stages are carried out by the teacher who builds students' interest at the beginning of learning. The stages of initiation and acquisition, elaboration, incubation and encoding memory, verification, and checking of trust, are applied by the teacher who engages students directly in understanding concepts, optimizing the brain work, creating meaningful learning and training students' thinking ability.

In this study, another factor that became the focus of research was the mathematical preliminary skill (MPS) (high, medium, low). This is to determine whether the increase after applying BBL approach in learning mathematics is evenly distributed to all categories of student abilities. If there is an increase of each MPS, learning with a BBL approach might be applicable to all levels of student ability.

\section{METHODS}

This quasi-experimental was conducted with nonequivalent control group design. We used quantitative method to compare the two group of enhancement of students` mathematical problem-solving ability. The two groups of students were taught by using different approaches; Brain-Based Learning (BBL) and Conventional Learning (CL). The object of the study was the students in 7th-grade of the junior high schools in Padang city. The topic chosen in this study is geometry. The data collecting instrument is tested. A test instrument was given to the students to measure their MPS and mathematical problemsolving ability. Results from both tests were statistically analyzed. The results obtained from MPS test was used to conclude the students' ability in both classes, also based on categories of MPS. Mathematical problem-solving ability test was used at the time of pretest and posttest in order to 
specify the enhancement of the students' mathematical problem-solving ability in both classes.

To analyze the data obtained from the pretest and posttest we do: (1) Calculating the descriptive statistics of the pretest and posttest scores; (2) Deciding the students' enhancement by finding the post-test score; (3) Calculating the enhancement by using normalized gain (N-gain) formula. $\mathrm{N}$ gain calculation results were interpreted by following the classification of Hake's [9]. (4) Using a normality test and homogeneity variance of data distribution; (5) Testing the research hypotheses; and (6) Concluding the effect of the BBL and CL through mathematical problem-solving ability based on MPS.

\section{RESULTS AND DISCUSSION}

The enhancement of mathematical problem-solving ability in experimental and control class were analyzed based on MPS (high, medium, small). A score of pre-test, post-test, and N-gain of mathematical problem-solving ability based on MPS were shown in the following table.

TABLE I. THE SCORE OF PROBLEM SOLVING ABILITY BETWEEN EXPERIMENTAL AND CONTROL CLASS.

\begin{tabular}{|c|c|c|c|c|c|c|c|}
\hline \multirow{2}{*}{ MPS } & \multirow{2}{*}{ Score } & \multicolumn{3}{|c|}{ Experiment (BBL) } & \multicolumn{3}{|c|}{ Control (CL) } \\
\hline & & $\mathbf{N}$ & $\overline{\boldsymbol{x}}$ & SD & $\mathbf{N}$ & $\overline{\boldsymbol{x}}$ & SD \\
\hline \multirow{3}{*}{ High } & Pretest & \multirow{3}{*}{6} & 7,5 & 0,55 & \multirow{3}{*}{5} & 7,4 & 0,55 \\
\hline & Posttest & & 14,67 & 0,82 & & 13 & 0,71 \\
\hline & $\mathrm{N}$-gain & & 0,84 & 0,10 & & 0,65 & 0,07 \\
\hline \multirow{3}{*}{$\begin{array}{l}\text { Mediu } \\
\mathrm{m}\end{array}$} & Pretest & \multirow{3}{*}{13} & 4,69 & 1,11 & \multirow{3}{*}{13} & 4,69 & 1,03 \\
\hline & Posttest & & 10,62 & 1,19 & & 9,31 & 1,75 \\
\hline & $\mathrm{N}$-gain & & 0,52 & 0,09 & & 0,41 & 0,11 \\
\hline \multirow{3}{*}{ Low } & Pretest & \multirow{3}{*}{6} & 0,67 & 0,82 & \multirow{3}{*}{7} & 0,57 & 0,53 \\
\hline & Posttest & & 6,67 & 0,52 & & 4,43 & 1,13 \\
\hline & $\mathrm{N}$-gain & & 0,39 & 0,03 & & 0,25 & 0,06 \\
\hline
\end{tabular}

The results of normality test N-gain based on MPS (High) by using Saphiro-Wilk are 0.243 for experimental class and 0.852 for the control class. The criteria for making the results of the normality test are if the Sig Value. (P-value) $<\alpha(\alpha=$ $0.05)$, then $\mathrm{HO}$ is rejected and if the value is Sig. (p-value) $\geq$ $\alpha(\alpha=0.05)$, then H0 is accepted. They can conclude that HO is accepted. It means the data of $\mathrm{N}$-gain mathematical problem-solving ability score based on MPS (high) was normally distributed. The result of homogeneity test $\mathrm{N}$-gain based on MPS (High) by using Levene is 0,208. It means that the data of $\mathrm{N}$-gain mathematical problem-solving ability score based on MPS (high) was homogenous. A hypothesis test is using t-test. The result of t-test was shown in the following table.

TABLE II. RESULT OF T-TEST

\begin{tabular}{|c|c|c|c|}
\hline \multicolumn{3}{|c|}{ t-test equality of means } & \multirow{2}{*}{ Conclusion } \\
\hline $\mathbf{t}$ & $\mathbf{d f}$ & Sig. (2-tailed) & \\
\hline 2,148 & 8 & 0,06 & H0 is rejected \\
\hline
\end{tabular}

Based on Table II, it can conclude that $\mathrm{HO}$ is rejected. It means that the enhancement of mathematical problemsolving ability of students who learn with Brain-Based Learning (BBL) approach was significantly higher than students who learn with conventional learning (CL) based on MPS (High).
The results of normality test N-gain based on MPS (Medium) by using Saphiro-Wilk are 0.125 for experimental class and 0.264 for the control class. They can conclude that $\mathrm{HO}$ is accepted. It means that the data of $\mathrm{N}$-gain mathematical problem-solving ability score based on MPS (Medium) was normally distributed. The result of homogeneity test $\mathrm{N}$-gain based on MPS (Medium) by using Levene is 0,413 . It means that the data of $\mathrm{N}$-gain mathematical problem-solving ability score based on MPS (Medium) was homogenous. Hypothesis test of the data mathematical problem-solving ability both class based on MPS (medium) was shown in the following table

TABLE III. RESULT OF T-TEST

\begin{tabular}{|c|c|c|c|}
\hline \multicolumn{3}{|c|}{ t-test equality of means } & \multirow{2}{*}{ Conclusion } \\
\hline $\mathbf{t}$ & df & Sig. (2-tailed) & \\
\hline 2,845 & 24 & 0,009 & \multirow{2}{*}{ H0 is rejected } \\
\hline
\end{tabular}

Based on Table III, it can conclude that $\mathrm{HO}$ is rejected. It means that the enhancement of the mathematical problemsolving ability of students who learn with Brain-Based Learning (BBL) approach was significantly higher than students who learn with conventional learning (CL) based on MPS (Medium).

The results of the normality test $\mathrm{N}$-gain based on MPS (Low) by using Saphiro-Wilk are 0.554 for experimental class and 0.089 for the control class. They can conclude that $\mathrm{H} 0$ is accepted. It means that the data of $\mathrm{N}$-gain mathematical problem-solving ability score based on MPS (Low) was normally distributed. The result of homogeneity test N-gain based on MPS (Low) by using Levene is 0,117 . It means that the data of $\mathrm{N}$-gain mathematical problem-solving ability score based on MPS (Low) was homogenous. Hypothesis test of the data mathematical problem-solving ability both class based on MPS (low) was shown in the following table.

TABLE IV. RESULT OF T-TEST

\begin{tabular}{|c|c|c|c|}
\hline \multicolumn{3}{|c|}{ t-test equality of means } & \multirow{2}{*}{ Conclusion } \\
\hline $\mathbf{t}$ & df & Sig. (2-tailed) & \\
\hline 5,390 & 11 & 0,000 & H0 is rejected \\
\hline
\end{tabular}

Based on Table IV, it can conclude that $\mathrm{H} 0$ is rejected. It means that the enhancement of the mathematical problemsolving ability of students who learn with Brain-Based Learning (BBL) approach was significantly higher than students who learn with conventional learning (CL) based on MPS (Low). Based on the results of the study and statistics test, learning process by using BBL approach can enhance mathematical problem-solving ability significantly based on MPS (High, Medium, Low).

Learning process based on BBL is the learning that follows how the brain works and process the knowledge [10]. BBL approach provides a concept to create the learning which maintains and improve the ability of brain hence it could increase the problem-solving ability of students [8]. The BBL approach is the way of study which explores the whole of brain functions. He also conceded that not all students could study in the same way [11]. The main purpose of $\mathrm{BBL}$ is to direct the learning from memorizing into another more meaningful method, so that the students 
hopefully improve their ability in solving a mathematics problem [12].

In the stage of pre-exposure, the teacher increases the problem-solving ability of the students by giving the explanations before they get further information. This stage eases the student to take the information. The more knowledge that possessed by the student, the more connections they could apply to solve the problem [7]. In another hand, the teacher invites the student to practice a brain game in order to focus the attention of the student before the learning process.

In the stage of preparation, the teacher gives a real example in the daily activity. According to Jensen, the most effective way to teach thinking skills is by inserting the daily life problem into an authenticable condition. The students are expected to have an ability to increase the problem-solving ability through analyzing the real daily problem.

At the stage of initiation and acquisition in BBL, the teacher provides a real experience to students through the completion of the Student Worksheet (LKS). The questions given by the teacher in LKS are questions that can increase students' mathematical problem-solving skills. The provision of many tasks and activities in learning can improve the working system of the brain in absorbing information. Training the students to solve the problem is one of the efforts to improve mathematical problem-solving abilities. The BBL approach problem solving is one of the efforts to teach students' thinking skills. In addition, giving students non-routine problem-solving problems has a positive impact on activating the brain work system [7]. Problem-solving for the brain is like aerobic exercise for the body [7]. That is, the provision of challenge, novelty, and complex assignment of problem-solving problems that require intense thinking is very good for the brain.

At the elaboration stage, the teacher asks students to present the results of the discussion and elaborate on the understanding of the material. At the verification and confidence checking stage, the teacher checks the material students have learned by asking students to write a journal. In addition, confidence checking is also carried out by giving quizzes both verbally and in writing. The more learning that is generalized, contextualized, and framed again, the more learning students get. Deep learning requires implementation and feedback [7]. Thus, the application of BBL stages in learning mathematics can improve students' problem-solving abilities.

\section{CONCLUSION}

We revealed the differences ability between BBL and MPS approaches. BBL was better than MPS approach which indicated that further learning should use BBL, especially in the topic of geometry.

\section{ACKNOWLEDGMENT}

The authors would like to express their appreciate to students and also mathematics' teacher that help on get the data this research.

\section{REFERENCES}

[1] Sumarmo. U., Hendriana. H, Penilaian pembelajaran matematika. Bandung: Refika Aditama, 2014.

[2] Martin. M. O., Mullis. I. V., Foy. P., \& Stanco. G. M, TIMSS 2015 international result in mathematics, Chestnut Hill: TIMSS \& PIRLS International Study Center, 2015.

[3] Tim Pusat Penelitian Pendidikan Badan Penelitian dn Pengembangan Kementrian Pendidikan dan Kebudayaan. Kemampuan matematika siswa SMP Indonesia menurut Benchmark International TIMSS 2011. http://litbang.kemdikbud.go.id/data/puspendik/HASIL\%20RISET/TI MSS/LAPORAN\%20TIMSS\%202011\%20-

20Kemampuan\%20Matematika\%20Siswa\%20SMP\%20Indonesia\%2 Oberdasarkan\%20Benchmark\%20TIMSS\%202011.pdf [Accessed 13 April 2018]

[4] Rusyda. N. A, "A cognitive Analysis of Students` Mathematical Problem Solving Ability on Geometry", Journal of Physics: Confrence Series 895, 2017

[5] Sumartini. T. S, "Peningkatan kemampuan pemecahan masalah matematis siswa melalui pembelajaran berbasis masalah", Jurnal Musharafa, vol. 8, pp. 11-21, 2016.

[6] Anisa. W. N, "Peningkatan kemampuan pemecahan masalah dan komunikasi matematik melalui pembelajaran pendidikan matematika realistik untuk siswa SMP Negeri di Kabupaten Garut", Jurnal Pendidikan dan Keguruan 1, vol. 1, 2014

[7] Jensen. E, Brain based learning, Yogyakarta: Pustaka Pelajar, 2008.

[8] Sapa`at. A, Brain based learning. (Online) Diakses dari : http://matematika.upi.edu/index.php/brain-based-learning/. [Accessed 13 April 2017], 2009.

[9] Hake. R.R, Analizing Change / Gain Scores. [Online]. Available: http: // www.physics.indiana.edu/-sdi/AnalyzingChange-Gain.pdf. [Accessed 13 April 2017], 1999.

[10] Jensen. E, Pemelajaran berbasis-otak, Jakarta: Indeks, 2011.

[11] Duman. B, "The effect of brain-based instruction to improve on students' academic achievement in social studies instruction", 9th International Conference on Engineering Education, vol. 24, pp. 1725, 2006.

[12] Caine. R. N., \& Caine. G, "Understanding a brain-based approach to learning and teaching", Educational Leadership, vol. 48, pp. 43-47, 1990 . 